\title{
Reflections on a Decolonial Humanities and the Lived Experience of the Subaltern in South Africa
}

\author{
Rajendra Chetty
}

\section{Abstract}

The aim of this article is to reflect on the imperative for a decolonial humanities in the context of social inequality and neo-colonialism in post-apartheid South Africa. The article leans on the emancipatory lens of Fanon's revolutionary humanism that positions the role of scholar 'inside' the struggle of people and views practice/activism/civil society resistance as a product of philosophy. In their critical analysis of human rights discourse, Mignolo (2000) and Spivak (1999) focus on the question of 'who speaks for the human in human rights?' and the twofold problem of silence that gives consent for oppression and experts who address the denial of rights among the subaltern, concomitant with the dis-authorization of their interpretive perspective. The poor are neither silent nor in need of expertise to speak 'for' them. They are engaged in the process of affirming their humanity as witnessed in the increased civil society uprisings. The silence of the academe has led to us standing outside the 'real' struggles of the disenfranchised masses.

The article advocates for the creation of a new kind of humanities education, a 'decolonial humanities' that engages with inequality, injustice and lived experiences of poor people. The humanities generally ignore the world outside the university - a performative contradiction of denying humanity in the very process of seeking to affirm human rights. The decolonial humanities are found mainly outside universities - in social, artistic, and intellectual movements. Contributing to those projects is critical for securing progressive and transformative social change. The lack of substantive attention to the lived experience and condition of the marginalized is a continuation and reinforcement of colonialism. 
Keywords: Decolonization, humanities, dehumanization, Fanon, subaltern, revolutionary humanism

\section{Introduction}

The term 'humanities' in South Africa refers to the 'traditional' humanities disciplines, the social sciences and the arts (ASSAf 2011:19). The humanities curriculum generally ignores the world outside the university given the dominance of western theoretical paradigms, minimum impact of research on society and little material impact on people who experience colonial violence on a daily basis. I reflect on teaching and research over three decades in the humanities. Reflective practice involves paying critical attention to the practical values and theories that inform actions like teaching and research, by examining practice reflectively and aiming for developmental insight. A key rationale for reflective practice is that experience alone does not necessarily lead to learning; deliberate reflection on experience is essential (CochranSmith \& Lytle 1999:250). I focus specifically on the lack of responsiveness of the humanities to the social context and its silence on the lived experiences of the subaltern. This is a performative contradiction of denying humanity in the very process of seeking to affirm a just, equal and human rights culture in postapartheid South Africa as espoused in the constitution of the country.

Essential to the current decolonization project is the call for a transforming humanities curriculum that acquires concreteness, relevance and purpose by being located within a specific social, economic, environmental, intellectual, political and legal context. Central to the teaching and research agenda of the humanities should be questions concerning development, social justice and human rights. This would entail foregrounding marginalized narratives, voices and subjugated knowledges of the 'other'. In contrast, a decolonial humanities is found mainly outside universities - in social, artistic, intellectual and civil society movements. Contributing to those projects is critical for securing progressive and transformative social change. The call is for curriculum transformation as a decolonizing project that starts from the premise of re-centring narratives that have been rendered invisible and misrepresented by the structures of colonialism and apartheid. Decolonization, as Ngũ g1 wa Thiong'o (2004:88) argues, is about rejecting the centrality of the West in Africa's understanding of itself and its place in the world. It is 
about recentering ourselves and placing Africa in the centre concomitant with understanding and recognizing the reality of African lives. The lack of substantive attention to the lived experience and condition of the marginalized other, the subaltern, is construed as a continuation and reinforcement of colonialism. Gramsci (1971) used the term 'subaltern' interchangeably with 'subordinate' to describe non-hegemonic groups or classes.

The need for re-thinking knowledge in the humanities is urgent given the current context of increased mass resistance, neo-colonial approaches of the state and student demands for institutional reform. An important step is to take some distance from the dominant philosophies, discourses and practices and detect its mechanisms of operation, whether it emerges from the north or south and the places where it has effect. Most disciplines in the humanities lean towards Eurocentric indoctrination that marginalizes Africa and often reinforce patronizing views and stereotypes about the continent. In departments like English and Philosophy, European and white values are perceived as the standards on which the curriculum is rooted. When South African literature is included in the English curriculum as part of the transformation exercise, it consists mainly of the 'little white canon' and excludes black African writers and theorists.

It is necessary to question philosophical and theoretical discourses that underpin curricula, to make political change in theory and in so doing to recognize different ways of knowing and being:

... to assume a political position that makes possible an other discursive strategy, other philosophical work, and opens other spaces of theoretical production (Walsh 2012: 11).

Catherine Walsh clarifies that it is these other places, spaces, and positions, other philosophies and other knowledge that challenge not only the definitions and boundaries of philosophy's continental-analytical divide, but also the geopolitical ordering of knowledge and the questions of who produces knowledge, how and where, and for what purposes (2012:11). The dilemma in the humanities is that canonical traditions of knowledge production has become hegemonic together with the dominance of conservative academics that actively reinforce these traditions in the guise of values and standards. This hegemonic notion of knowledge production has generated discursive scientific practices and has set up interpretive frames that actively represses anything that is 
articulated and thought from outside of these frames. They involve a particular anthropological knowledge, which is a process of knowing about native/ indigenous/ barbarian others - but a process that never fully acknowledges the other as thinking and knowledge producing subjects. The epistemic traditions of the other are disregarded - Santos (2007) prefers the terms 'epistimicide' and 'cognitive injustice'. While acts of social justice are used to legitimize previously marginalized communities (correcting the wrongs of the apartheid/ colonial past), cognitive justice as a prerequisite, recognizes the presence of different forms of understandings, knowing and explaining in the world.

Colonialism has become a normal form of social relations rather than a system of exploitation. Colonial epistemic traditions claim detachment of the known from the knower. The scholar is enclosed in herself and produces supposedly objective knowledge of the subaltern. The knowing subject is thus able to know about the shackdwellers, the ghetto experience and life on the 'other side of the line' (Santos 2007), without being part of that world and able to produce knowledge that is supposed to be universal and independent of context.

The challenge is how to situate knowledge production in the local histories and struggles of the other. Edward Said (1978:2) argues that the western discourse about the other is supported by 'institutions, vocabulary, scholarship, imagery, doctrines, even colonial bureaucracies and colonial styles'. The scholars, using western modes of research, do not engage with the voices of the subaltern, but speak and think 'for' them through imaginative constructions of their lived experience. Said reasons that scholarly construction is supported by western knowledge traditions and institutional practices which 'makes statements about it [the Orient], authorizing views of it, describing it, by teaching about it, settling it, ruling over it' (1978: 3). This questions the very credibility of western knowledge claims of the subaltern as the formal scholarly pursuits of knowledge and the informal, imaginative, anecdotal constructions of the other are intertwined with each other and with the activity of research (Said 1978:2).

The commitment should be towards a radical humanism that engages with the voices of the subaltern. Linda Tuhiwai Smith (2008) notes that the struggle to assert humanity and claim voice has been a consistent thread of anti-colonial discourses on oppression:

This struggle for humanity has generally been framed within the wider discourse of humanism, the appeal to human rights, the notion of a 
universal human subject, and the connections between being human and being capable of creating history, knowledge and society (2008: 26).

The struggle for humanity in South Africa is complicated by the intersectionality of colonialism, apartheid, race, class and gender. The colourblindness, rainbowism and reconciliation agenda of the post-1994 state are viewed by the subaltern as elements of a failed liberation (Gibson 2011:xiv). Reactionary and conservative forces have co-opted nonracialism, which they now equate with colour-blindness, and use nonracialism as a weapon to discredit any attempt to deracialize property, institutions and structures inherited from an hateful past (Mbembe 2015). More appropriate would be a resolute antiracist discourse after an era of racial repression. Ironically, the rhetoric of witness of the Truth and Reconciliation Commission (TRC) and the performance of forgiveness for atrocities against black bodies was seen as a step towards healing by the Mandela government. The deepened racism in South African society points to the consequences of colour-blindness. The Black Consciousness Movement anticipated this danger much earlier:

... there is conservative liberalism where the goal is to be colourblind. The problem with this kind of liberalism is that it changes no structures. Thus, this liberalism expects us to be colourblind in a world of white normativity (Biko 2002:x).

The healing of the 'damned of the earth' was expected to emerge post-1994 without fostering a new humanity for the victims of apartheid. The enhancement of the lived experiences of black people would have been justice in its deepest sense.

\section{Colonial Violation and its Continuity}

The age of modern colonialism in Africa began about 1500 with the Portuguese discovery voyages for gold in Upper Volta (Burkina Faso) and discovery of a sea route around the Cape of Good Hope in 1488. The scramble for Africa started in the 1860s when the French and the British began the systematic exploration of West Africa, signing bilateral agreements on spheres of influence. They were joined by Germany, Portugal, Belgium and Italy (in spite of the latter's claim that 'occupation' is not colonization). Europe signed 
treaties that divided Africa into protectorates, free-trade areas, and colonies. The essence of imperialism was structured into land, the economy, language, social relations and the cultural life of colonial societies. The key event of Europe's violation of Africa is the conference that Otto von Bismarck organised in Berlin in November 1884 - it came to symbolise ethnic partitioning and laid down the principles that would be used among Europeans to divide the continent (Michalopoulos \& Papaioannou 2011:8). It was a European affair with no representation of the 'savages', and African concerns were completely marginal to the economic, strategic, and political interests of the colonizers (Asiwaju 1985).

Ironically, colonialism was clothed within an ideology of humanism and liberalism and the assertion of moral claims which related to a concept of civilized 'man' (Tuhiwai Smith 2008:26). When we fast-track to the current situation in Africa, it is evident that the violence and destruction of colonialism continues within political and social conditions that perpetuate extreme levels of poverty, chronic ill health and poor educational opportunities among the colonized. Born during the high period of neoliberal globalization, the Mandela government silenced more radical alternatives by trading on its credentials as the party of liberation coupled with a succession of neoliberal restructurings (Gibson 2011:xiv). The trading on struggle credentials and lack of concrete links between radical intellectuals and the masses resonates with Fanon's notion of 'intellectual laziness' (1967:148). The celebrations of freedom over the past two decades in the face of increased social revolts, isolation of the poor from bourgeois spaces and state capture/corruption resonates with Fanon's prediction of 'the fancy dress parade' (1967:147). The ethical shift among the freedom fighters and emerging black middle class was manifested in individual greed and 'cadre deployment'/ 'pay-off' with jobs in a new bloated public service, national and provincial governance structures and statutory bodies created to advance the new democracy.

The incongruity of the democratic dispensation is that the subaltern continues to live in impoverished and destructive conditions, cannot afford basic necessities, namely water, electricity and housing, and endure increasing levels of violence and crime. Politically, the continuity with colonialism/ apartheid is evident in endless social revolts, militant student resistance (\#Feesmustfall), new stages of insurgency by workers (Marikana) and high levels of state corruption. It is the wretched of the earth that bear the brunt of the abuse of power in the quest for sheer physical survival as witnessed in the 
massacre of striking miners at Marikana in 2012. While the poor resist and rethink a philosophy of liberation, Tuhiwai Smith comments that they are constantly fed messages about their worthlessness, laziness, dependence and lack of 'higher' order human qualities (2008:26). The point that is ignored is the role of colonialism in the historical formation of the conditions within which the dehumanized live today. Colonialism has denied the subaltern their humanity and the state's neo-colonial agenda continues to dehumanize them, as would be discussed later with the experience of shack dwellers.

The dysfunctionality of democratic capitalism is evident in the inability in deracialising the economic system and failure to alleviate social deprivation inherited from apartheid. The weakness of most antiracist struggles is the result of our inability to keep up with the mutating structures of racism (Mbembe 2015). May (2000:263) concurs that the distortions and dynamics introduced by apartheid continue to reproduce inequality and has led to a worsening of poverty. Terreblanche (2016:30) identifies four poverty traps inherent in the socio-economic situation of the poor that is responsible for their further pauperisation despite increased social spending by the post-apartheid state:

i. High and rising levels of unemployment in a sluggish economy;

ii. Deeply institutionalized inequalities in the distribution of power, property, and opportunities between the white and black elite and the poorest half of the population;

iii. Disrupted and fragmented social structures and the syndrome of chronic community poverty among the poorest $50 \%$ of the population; and

iv. The mutually reinforcing dynamics of violence, criminality, and illhealth on the one hand and the process of pauperisation on the other.

A powerful myth of the post-1994 South African society is that the elimination of apartheid amounted to the decolonization of the country. The subaltern dismisses the myth effectively:

The hypocrites in the ANC continue to speak about land reform in parliament and in the media while violently evicting black people in the cities, like the apartheid government did. They do not recognise our humanity. We are treated like animals (Abahlali baseMjondolo 2018a). 
Black people have experienced the political transition of 1994 as a largely legal emancipation with equality before the law, but this has not translated into socio-economic empowerment. Capitalism still relies for its operations on racial subsidies in the form of low skill levels, inadequate nutrition, poor health, bad housing, social instability and an increasingly authoritarian ruling elite. The exploitation of cheap black labour remains a crude fact of daily life, especially on farms and mines, where migrant wage-seekers face adverse economic contingencies as they try to leverage their way out of poverty and insecurity (Mbembe 2015).

The dispossession and relocation by the Group Areas Act in racial ghettos institutionalised a sydrome of poverty among poorer black people and created a distinct poverty mentality marked by deviant behaviour patterns (Terreblanche 2016:40). This vicious cycle of poverty has not been broken through an effective and comprehensive policy of social upliftment in spite of claims stated in the 1994 Reconstruction and Development Programme (RDP) document that no political democracy can survive and flourish if the masses remain in poverty, without land, without tangible prospects for a better life. Ironically, the RDP document also indicated that attacking poverty and deprivation must be the first priority of a democratic government. The continued state of social inequality is the creation of a society that violates its most basic political precept that underlie its democractic claims. When applying the upper bound poverty line, 55.5\% (30.4 million) South Africans were poor in 2015 (Statistics South Africa 2017:14). Poverty has many dimensions beyond a lack of money. The need for a better understanding of the multiple ways people experience poverty is gaining momentum, as is the importance of measuring the often overlapping deprivations people face. Understanding both is vital for better decision making. This has obvious parallels with human development, a full understanding of which requires considering many dimensions of life, ranging from health, education and income through voice and empowerment. The Human Development Index places the country at 113 out of 189 countires. The quality of health, education and standard of living of poor people is low. The indicators on quality of standard of living are the proportion of employed people engaged in vulnerable employment (16.4\% of employed people live on less than $\$ 3.10$ per day), the proportion of rural population with access to electricity, the proportion of population using improved drinking water sources and improved sanitation facilities. 
South Africa's life expectancy at birth is below that of Namibia and Congo, countries with a far lower per capita GDP. In fact, Congo's GDP is 5,694 compared to SA's 11,923. The human inequality coefficient for South Africa is equal to 30.3 percent (Statistics South Africa 2017:20). As the inequality in a country increases, the loss in human development also increases. The lack of financial means, power and a sense of usefulness aggravates the depressing effects of poverty and gives rise to tension, frustration, alienation and fatalism.

The exceptionally high levels of deviant behaviour stems from this restrictive environment and represents a defensive adjustment to the stresses and strains of poverty in an advanced society (Terreblanche 2016:41). The experience of vertical violence during apartheid has extended to horizontal violence in disadvantaged communities, where the perceived 'weakest' members of society are the targets of abuse and violence. For example, about 900 children are murdered in South Africa every year on average (Institute for Race Relations 2017). The physical neglect of poor children is particulary significant during their critical formative years as they are exposed to such negative influences that they may be unable, even under favourable conditions, to regain lost ground later in life. Anxiety complexes and a negative self-image take root, while defensive traits are developed to ward off the physical and psychological stresses of their disruptive social environment (Terreblanche 2016:41). The dynamics of crime, gender-based violence, gangsterism, drug abuse and more recently, school violence, are therefore rooted in repression, discrimination, political struggle and social deprivation. Louw and Shaw (1997:12) agree that interpersonal violence in postcolonial societies occurs most frequently among people subject to the pressure of structurally entrenched economic and racial inequalities underpinned by systemic dehumanization.

Fanon's new humanism emerges in and from a dialogue with the poor. His analysis distilled from the Algerian struggle parallels the form and content of the new African nationalist elite, what Fanon (2017:13) terms the 'underdeveloped bourgeoisie'. The litany of crimes of corruption and maladministration of the new elite is catastrophic. South Africa has entered a new period of its history: a post-Machiavellian moment when private accumulation no longer happens only through dispossession but through the capture and appropriation of public resources, the modulation of brutality and the instrumentalisation of disorder (Mbembe 2015). 
We should note that the new regime is not much different from the Afrikaner Nationalist regime that it replaced in 1994 that left the country bankrupt with its looting of the state coffers. Fanon's prediction on the continutity is accurate:

The national bourgeoisie discovers its historical mission as intermediary. Its vocation is not to transform the nation but prosaically serve as a conveyor belt for capitalism, forced to camouflage itself behind the mask of neocolonialism. A hedonistic mentality prevails because on a psychological level it identifies with the western bourgeoisie from which it has slurped every lesson. It mimics the western bourgeoisie in its negative and decadent aspects (Fanon 2017: 37).

It is difficult to ascertain whether the problems of the post-apartheid South Africa are unique or is it, as predicted, repeating the experiences of other African independence movements that were unable to extricate themselves from the structures and discourses of the colonial regime (Gibson 2011:110). Fanon's understanding of the neo-colonial psyche is insightful:

The people find out the iniquitous fact that exploitation can wear a black face, or an Arab one, and they raise the cry of 'treason'! But the cry is mistaken; and the mistake must be corrected. The treason is not national but social (1967:145).

While the negotiated settlement in South Afica provided the framework for the continuation of the class structure, which has been made all the more hegemonic through the development of a black middle class, Gibson (2011:110) poses the larger critical question: how long will the masses of black people wait for fundamental improvements in their lives?

\section{A Decolonial Humanities - Speak to us, not about us}

A decolonial humanities would take cognizance of the resistance of poor communities in their ignored spaces, not in a demeaning manner where the experts speak for the poor. The subaltern vehemently reject the latter with remarks like: 'we are poor, not stupid' (Figlan et al. 2009:69). Their struggle to retrieve their humanity has to be recognized as they remake themselves 
through their subversive actions characterized by barricading their spaces with burning tyres and raising their voices against the new masters - the field slaves that have inherited, but not dismantled, the master's house.

The intellectualism of community movements that are emerging from informal settlements like Abahlali baseMjondolo is engaged in the praxis of transforming their spaces of marginalization into spaces of resistance and hope. Fanon (1967:147) emphasized 'praxis', positing the idea of 'enlightened' practice, the notion of practice as a product of philosophy through engagement with 'real' movements of the excluded masses that struggle for social change. Gramsci also expressed the idea of the militant philosophic praxis and the intimate connection between knowledge and action:

The philosophy of praxis is consciousness full of contradictions, in which the Philosopher himself (or herself) understood both individually and as an entire social group, not only grasps the contradictions, but posits himself (or herself) as an element of the contradiction and elevates this element to a principle of knowledge and therefore action (Gramsci 1971:405).

In contrast to the radical humanism agenda of the subaltern, focus by the humanities on intricacies, nuances or indeterminacies of the historical process contribute to the invisibility of coloniality (Grosfoguel 2009:12). It is not accidental that the insistence on pointing at the continuities of colonial mechanisms of exclusion most often comes from the subaltern groups, and not from scholars in the academic world (Grosfoguel 2009:12). Mignolo (2000) reminds us that we always speak from a particular location in the power structures and no one escapes the class, sexual, gender, spiritual, linguistic, geographical, and racial hierarchies of the modern, capitalist and patriarchal world-system. All knowledges are situated - black feminist scholars called their perspective afro-centric epistemology (Collins 1990), Dussel called it geopolitics of knowledge (2003) and Fanon (1967) and Anzaldua (1987) use the term, 'body-politics of knowledge'. Grosfoguel (2009:15) concurs that all knowledges are epistemically located either in the dominant or the subaltern side of the power relations and that this positioning is related to the geo- and body-politics of knowledge.

Essential to the other philosophies and knowledges is what Fanon called the actional, subjective and situated dimension of being human. A 
decolonial humanities will recognize and make visible the pedagogy and praxis of other epistemological logics and constructions and their theoretical, ethical, and political potential; a pedagogy and praxis that find their base in the lived struggles that modernity/coloniality have engendered (Walsh 2012:22). The priority for the radical intellectual is to reflect seriously on the ways academic practices signify, restrain, or empower decolonial turns not only in the curricula but also in real-life concerns of domination, emancipation, justice, and liberation of the increasing number of poor people in society (Walsh 2012:22). The current engagement by decolonial activists with the complex context of the north and south has to include the hybrid spaces of the "norths in the south', particularly in light of South Africa's continued spatial injustice, and constant pushing of the poor out of the cities as witnessed currently in Woodstock and Salt River (Cape Town). The obligation is to extend the decoloniality discourse of constructions of global imperialism and global coloniality to local struggles with regard to other maps, other places, and subaltern geopolitical positionings.

Humanities research should engage with how the lived experience of the subaltern portrays a realistic picture of the truths of resistance to the capitalist social order, vital for social change. In much of the academic endeavours, it is not the voices or intellectual production of the subaltern that is foregrounded, but rather the interpretation and utility of their experience from a scholar's perspective. A shack-dweller's response on the expert's reasoning on shack fires is poignant:

We have heard many people suddenly becoming experts on shack fires. Some are saying the reasons that shack fires exist is because we build too close to one another. Others blame the forms of lighting or heating that people use. In some cases alcohol is said to be the cause of the fires. It is typical for middle class and elite people to think in this way. They want to blame the oppressed for their suffering rather than to blame the systems that cause oppression (Abahlali baseMjondolo 2018a).

As recent as November 2019 a multi-million rand United Kingdom Research and Innovation grant (UKRI GCRF Water and Fire: Enhancing capacity and reducing risk through 15 'Best Bets' for transformative adaptation with vulnerable residents on the Cape Flats) was awarded to Stirling University for 
research in informal settlements in the Cape Flats. The research team consists only of white academics from two Western Cape universities and two white community workers. The latter would receive the lion's share of the funding for their 'intervention work' with fire and water in three sites. Conspicuously, civic organizations that currently engage with these issues have been excluded and the methodology is stuck in a colonial paradigm. It is evident that the anthropological process of knowing about the native is far from being disrupted given the financial power and developmental agenda of empire.

It is the intellectual practice of speaking for the subaltern that has generally characterized leftist thought in postcolonial countries; a practice that tends to reproduce and maintain subalternization (Walsh 2012:14). The drawback here is with the ways that leftist critical thinking (particularly among those who claim struggle credentials) continues to ridicule, complicate or invalidate the intellectual production that derives from community organizations.

Fanon's thinking is significant in relation to the problems of social and political transformation that have emerged, specifically the continuities of apartheid and its consequences for the poor:

Should they try to evict us, we will fight them. We are not prepared to move from here. People that are living here are very poor and have nowhere else to go. What must they do now? This is not council land. The Tshwane metro calls us land invaders, but we are South African residents looking for a place to stay with our children (Ngoepe 2015).

Land was at the heart of coloniality and it remains central to demands for redress. In 1915, Sol Plaatje wrote of the 'roving pariahs' who had been forced off white farms following the Native Land Act, which Plaatje called 'a legislative monstrosity' (Mzwakli 2019). But waves of evictions from commercial farms, many of them white-owned, have continued after apartheid. Attempts at redress, or to extend a degree of protection to farm workers, have incited new rounds of expulsion (Mzwakli 2019).

The continuity of the distrust of the state is a political paradox. There has been a marked resurgence of the oppositional language of emancipation of the 70s and 80s during current civil society protests. The difference, using the Fanonian lens and the narratives of the subaltern, is that the white colonizer has been replaced by a black elite: 
When you are living in shacks your life is vandalised by the state. The economy places no value on your dignity. When you are forced to live on a tiny piece of land with thousands of other people, when you are forced to build with wood, cardboard and plastic, and when you are not allowed to connect yourself to electricity, disasters are inevitable (Abahlali baseMjondolo 2018b).

Civil society maintains that liberation has been differed by the mimic-men who control the post-apartheid state:

We must unite as the oppressed, as impoverished people, and refuse to be used by politicians. We must build our own power and work to emancipate ourselves (Abahlali baseMjondolo 2018b).

The new narratives of liberation create the need for cognitive resources to revise the horizon of Third World politics, to imagine alternative hopes and to assemble the normative political strategies by means of which these hopes can be placed on the agenda of the present (Scott 1999: 200). Scott views a narrative of liberation as a structured story that progressively links through generative tropes as Repression, Alienation, Consciousness, Awakening, Resistance, Struggle, and Realization. The past and the present are characterized by Domination and the gaze is on an anticipated future of Freedom. The current struggle is overcoming the repressive power that denies the subjugated their essential humanity:

When you live in a shack in this country you are considered to be someone who cannot think. Your dignity is not recognized. You are left to live with the rats and the floods. You are left to burn. Your life does not count as a human life.

Almost 25 years after apartheid we are still condemned to indignity. We are still forced to live like pigs in the mud. We are still sentenced to die in the fires. When we refuse indignity and stand up for our humanity we continue to face arrest, assault, torture and assassination (Abahlali baseMjondolo 2018b).

The response to neo-colonial oppression is an emergent rebellion and takes the form of disorganized violence. Increasingly exposed to all kinds of risks to 
their lives, many now believe that each individual can be his or her own police, or that most disagreements are better settled by force (Mbembe 2015). Deeper engagement with why much of the violence among the poor is initially directed inward is critical at this juncture. Scott (1999:202) provides two reasons for these violent outbursts: they allow the colonized a concrete outlet for their pent-up rage; and second, they signal to the colonizer that there is too much disorder to continue ruling in the old way. Mbembe (2015) reasons that apartheid brutality was somatic and made a prisoner of the black body by the police, the military, the prison, the court, the mines and the farm. Postapartheid South Africa has not taken proper stock of the extent to which brutality and trauma has been internalised and are now redeployed in a molecular fashion in public and communal existence.

Scott (1999) is optimistic that the aggression and violence of the poor will be rechanneled away from themselves and given a political, and specifically anticolonial, focus:

This is a turning point. It is, for the colonized, the moment of Consciousness; the moment of Awakening - the creation of what one might call an anticolonial Will. The criminal is turned into an activist; Moreover, through this canalization of the violence of the colonized there also begins a period of psychic healing, the reconstitution of the alienated self of the colonized. The 'New Man' of whom Fanon speaks begins to emerge (Scott 1999:202).

There is a marked increase of brutality in physical and psychological spaces that the subaltern occupy with 14470 incidents of unrest in 2015 (the highest in the world). The levels are far greater than during the reign of Botha's regime in the 1980s. Instead of exercising their voice as citizens in a democracy, these are protagonists who have to turn to destruction of schools and public amenities during violent protests to be heard.

The situation is exacerbated with the increased militarization of the police and use of private security. A classic example is a private firm that is contracted by the state to evict shack-dwellers with their distinctive red overalls, hence the label 'Red Ants'. They usually carry pump action rifles that fire rubber bullets when they undertake evictions. The response from the shack dwellers is equally violent: 
When they [Red Ants] come back again, I'm going to shoot them. I'm going to shoot them .... Why do they destroy our properties? We have spent a lot of money to do this and we are not working. This shit government, I'm not scared of them (Bennie 2017).

The similarity with the 'Green beans' of the 1980s is striking - a police unit clad in green overalls and were brutal when expelling black families who encroached on white districts in Johannesburg (Sepolak 2017). Questions that remain unanswered are the legality of 'Red Ants' to be armed and the use by the Sheriffs of the Court of private security to carry out evictions. The claim by the highly militarized police of their fear of the people, hence the use of the 'Red Ants', is an interesting shift of power to the subaltern. The director of the 'Red Ants' claim ironically that they turn aggression into cooperation: 'We are not a fighting force. We are a force for normalisation in South Africa' (Moatshe 2014).

The forced-removal business is a booming new industry and often headed by white ex-police or ex-military officials from the old apartheid regime (Sepolak 2017). In the Western Cape province, the statistics of the latter half of 2018 of 'Red Ant' destruction of shacks indicate a marked increase in dehumanization of the poor - evictions occurred in Kleinmond, Zwelihle, Hermanus, Khayalitsha, Stellenbosch, Langa and Delft. The City of Johannesburg paid R20 million from 2014-17 to 'Red Ant' firms to destroy shacks and R22 million from September to November 2016 on 'monitoring and patrolling' land being invaded (Manda 2017). The line item for the former expense is irreverently labeled 'Citizen Relationship and Urban Management Unit' (Manda 2017). The state and police claim that the people are resistant to reason and negotiation. However, the people raise fundamental issues in their dissention:

When we take our own action to occupy good land, to build decent houses and to connect ourselves to water and electricity, the state criminalises our efforts.

The state always blames us. We are blamed for being homeless. We are blamed for moving to the cities to seek a better life. We are blamed for occupying land. We are blamed for trying to build homes for our families. We are blamed for making our own connections to water and electricity. Then the very people who are constantly 
blaming us for being oppressed while benefiting from the systems that oppress us then expect us to vote for them (Abahlali baseMjondolo 2018b).

\section{Conclusion}

A key challenge within the current decolonization discourse in the humanities is how to situate knowledge production in the local histories and struggles of the subaltern through engaging with their voices and agency. The epistemological problem should be central to the next phase of social transformation. The objective conditions of global impoverishment and the lived experiences of the poor should be at the centre so as to encourage critical dialogical encounters and 'epistemic disobedience'.

A decolonial humanities will disrupt academic populism that rewards scholarship that engages with the canon and dominant/settled knowledge in the disciplines, shows patriotism to the heroes of disciplines (who are largely white, dead, hetrosexual and male), churns out research output that has no social impact and establishes politically correct credentials, even with oppressive governments. The need for a radical intellectualization of decoloniality is urgent given the complex nature of the current context of student resistance and social revolts. The universities should be more than knowledge factories satisfying the demands of business and the state and producing foot-soldiers for capitalism.

The master's house has to be disrupted by engagement with radical humanism emerging from below and breaking the silence of the field slaves that have been converted into house slaves post-1994 in the humanities, what Fanon calls the conversion of the activist into the 'national bourgeoisie'. Academics should interrogate the role they play in turning higher education into a marketable product, how the hidden curriculum has subjugated the humanist agenda and their complicity in reinforcing the master narrative and academic cultural dogma. Scholarship and research cannot continue reproducing race and class inequities, especially after the decolonial turn heralded by the student uprising in 2015 . The humanities have to chart a course away from reproduction of unjust historical practices such as marginalising, invisibilising, silencing and alienating the other.

A decolonial humanities will recognize and engage with the subaltern 
struggle to move from alienated dehumanization to self-realisation. Those who have been racialized and dehumanized must be empowered to recover a modicum of self-agency and, if necessary, the kind of healthy narcissism that has been crushed during the long centuries of brutality. The issue of social inequality emanating from race and class discrimination is a moral issue. Hence, the humanities should be active in constructing a 'beyond' in which there emerges a new and unencumbered humanity.

\section{References}

Abahlali baseMjondolo 2018a. Shack Fires are our Daily Lives. Press Statement: 23 October 2018. Available at:

http://abahlali.org/node/date/2018/10/ (Accessed on 3 December 2018.) Abahlali baseMjondolo 2018b. Brutal Armed Attack on the eKhenana Land Occupation. Press Statement 08 November 2018. Available at:

http://abahlali.org/node/16808/ (Accessed on 3 December 2018.)

Academy of Science of South Africa (ASSAf) 2011. Consensus Study on the State of the Humanities in South Africa. Available at:

http://www.assaf.co.za/wp-content/uploads/2011/09/2011-Humanityfinal-proof-11-August-2011.pdf (Accessed on 12 November 2019.)

Anzaldúa, G. 1987. Borderlands: la frontera. Volume 3. San Francisco: Aunt Lute.

Asiwaju, A. 1985. The Conceptual Framework. Partitioned Africans. New York St. Martin Press.

Bennie, A. 2017. Red Ants Accused of Firing Rubber Bullets. Available at: https://www.dailymaverick.co.za/article/2017-07-14-groundup-red-antsaccused-of-firing-rubber-bullets/ (Accessed on 15 February 2019.)

Biko, S. 2002. I Write What I Like. Chicago: University of Chicago Press. https://doi.org/10.7208/chicago/9780226368535.001.0001

Dussel, E. 2003. Philosophy of Liberation. Oregon: Wipf and Stock Publishers.

Cochran-Smith, M. \& S.L. Lytle 1999. Relationships of Knowledge and

Practice: Teacher Learning in Communities. Review of Research in Education 24,1: 249 - 305.

https://doi.org/10.3102/0091732X024001249

Collins, P.H. 1990. Black Feminist Thought: Knowledge, Consciousness and 
the Politics of Empowerment. New York: Routledge, Chapman and Hall. Fanon, F. 1967. Black Skin, White Masks. New York: Grove Press.

Fanon, F. 2017. The Trials and Tribulations of National Consciousness. New Agenda: South African Journal of Social and Economic Policy 66:36 - 40. Figlan, L., R. Mavuso, B. Ngema, N. Nsibande, S. Sibisi \& S. Zikode 2009. Living Learning. Pietermaritzburg: Church Land Programme.

Grosfoguel, R. 2009. A Decolonial Approach to Political-Economy: Transmodernity, Border Thinking and Global Coloniality. Kult 6 - Special Issue Epistemologies of Transformation: The Latin American Decolonial Option and its Ramifications. Roskilde: Department of Culture and Identity. Roskilde University.

Gibson, N.C. 2011. Fanonian Practices in South Africa. From Steve Biko to Abahlali base Mjondolo. Pietermaritzburg: UKZN Press.

Institute of Race Relations. 2017. The State of the Nation 2017: The Silver Lining. Johannesburg: SAIRR.

Manda, S. 2017. Metros Pay Millions to 'Red Ants'. Mail and Guardian 13 June 2017. Available at: https://mg.co.za/article/2017-06-13-00-metrospay-millions-to-red-ants (Accessed on 5 December 2018.)

May, C. 2000. A Global Political Economy of Intellectual Property Rights: The New Enclosures? London: Routledge.

Mbembe, A.J. 2015. Decolonizing Knowledge and the Question of the Archive. Aula Magistral Proferida. Available at:

http://www.staugustine.ac.za/sites/default/files/ctools/13.\%20Mbembe\% 20-\%20Decolonizing\%20Knowledge...\%20\%282015\%29.pdf (Accessed on 15 Feburary 2019.)

Michalopoulos, S. \& E. Papaioannou 2011. The Long-run Effects of the Scramble for Africa. Cambridge, MA: National Bureau of Economic Research. https://doi.org/10.3386/w17620

Mignolo, W. 2000. Local Histories/ Global Designs: Coloniality, Subaltern Knowledges, and Border Thinking. Princeton, NJ: Princeton University Press.

Moatshe, R. 2014. Jo'burg Residents Battle Red Ant Evictions. Mail and Guardian 19 September 2014. Available at: https://mg.co.za/article/201409-18-joburg-residents-battle-red-ant-evictions

(Accessed on 4 December 2018.)

Mzwakali, S. 2019. A New Wave of Farm Evictions. New Frame 26 February 2019. https://www.newframe.com/new-wave-farm-evictions 
(Accessed on 28 February 2019.)

Ngoepe, K. 2015. We Will not Move - Soshanguve Squatters. News 24, 8 October 2015. Available at:

https://www.news24.com/SouthAfrica/News/We-will-not-move-

Soshanguve-squatters-20151008 (Accessed on: 10 December 2018.)

Ngũgĩ wa Thiong'o 2004. Decolonizing the Mind. The Politics of Language in African Literature. Nairobi: East African Educational Publishers Ltd.

Reconstruction and Development Programme 1994. Pretoria: Government Printers.

Said, E. 1978. Orientalism. London: Vintage Books.

Salopek, P. 2017. Army of 'Red Ants' Raids S. Africa Shanties. Available at: https://www.chicagotribune.com/news/ct-xpm-2002-01-21-0201210172story.html (Accessed on 26 February 2019)

Santos, B. de S. 2007. Beyond Abyssal Thinking: From Global Lines to Ecologies of Knowledge. Review XXX,1: 45 - 89.

Scott, D. 1999. Refashioning Futures: Criticism after Postcoloniality. New Jersey: Princeton University Press. https://doi.org/10.1515/9781400823062

Spivak, G.C. 1999. A Critique of Postcolonial Reason. Boston: Harvard University Press. https://doi.org/10.2307/j.ctvjsf541

Statistics South Africa 2017. Poverty Trends in South Africa. An Examination of Absolute Poverty between 2006 and 2015. Pretoria: Government printers.

Terreblanche, S. 2012. A History of Inequality in South Africa 1652 - 2002. Pietermartizburg: University of Kwa-Zulu Natal Press.

Tuhiwai Smith, L. 2008. Decolonizing Methodologies. New York: Zed Books Ltd.

Walsh, C. 2012. 'Other' Knowledges, 'Other' Critiques: Reflections on the Politics and Practices of Philosophy and Decoloniality in the 'Other' America. Transmodernity: Journal of Peripheral Cultural Production of the Luso-Hispanic World 1,3: 11 - 39.

Rajendra Chetty University of the Western-Cape Bellville $\underline{\text { rchetty@uwc.ac.za }}$ 